\title{
KEMAMPUAN PERAWATAN DIRI ANAK TUNA GRAHITA BERDASARKAN FAKTOR EKSTERNAL DAN INTERNAL ANAK
}

\author{
Dian Ramawati ${ }^{1,2^{*}}$, Allenidekania $^{3}$, Besral $^{4}$ \\ 1. PSIK FKIK Universitas Sudirman Purwokerto, Jawa Tengah 53123, Indonesia \\ 2. Program Studi Magister Fakultas Ilmu Keperawatan Universitas Indonesia, Depok 16424, Indonesia \\ 3. Fakultas Ilmu Keperawatan Universitas Indonesia, Depok 16424, Indonesia \\ 4. Fakultas Kesehatan Masyarakat Universitas Indonesia, Depok 16424, Indonesia \\ *Email:dian.ramawati@unsoed.ac.id
}

\begin{abstract}
Abstrak
Kemampuan perawatan diri anak tuna grahita, kemampuan perawatan diri dapat dipengaruhi oleh beberapa faktor, baik faktor eksternal (karakteristik orangtua dan lingkungan) maupun faktor internal (karakteristik anak). Penelitian ini bertujuan untuk mengetahui faktor-faktor yang berhubungan dengan kemampuan perawatan diri anak tuna grahita. Rancangan penelitian cross sectional dengan sampel adalah 65 orangtua anak tuna grahita di Sekolah Luar Biasa (SLB). Analisis data menggunakan uji Chi-Square dan regresi logistik ganda menunjukkan kemampuan perawatan diri pada anak tuna grahita masih rendah.Terdapat hubungan bermakna antara pendidikan orang tua, umur, dan kekuatan motorik pada anak tuna grahita dengan kemampuan perawatan diri $(\mathrm{p}<0,005)$. Faktor paling dominan yang mempunyai hubungan adalah faktor kekuatan motorik anak tuna grahita dengan $\mathrm{OR}=4,77$.
\end{abstract}

Kata kunci: Perawatan diri, faktor yang berhubungan, tuna grahita

\begin{abstract}
Children with mental retardation, self-care can be influenced by various factors, external (parents and environment characteristics) as well as internal (children characteristics). This study aimed to explore determinant factors that related to self-care ability in mental retardation children. Study design was cross sectional with samples are 65 parents whose mental retardation children registered in special education school. Using Chi-Square and Logistic Regression. Result of this study found that the self-care ability among retarded children is relatively low and there was significantly relationship between parents' education, children's age and gross motor performance to self-care ability in mental retarded children $(p<0,005)$. Gross motor performance of mental retarded children is the most dominant factor that contributed to self-care ability $(O R=4,77)$.
\end{abstract}

Keywords: Self-care, related factors, mental retardation children

\section{Pendahuluan}

Tingkat ketergantungan anak yang tinggi dalam melakukan kegiatan harian menjadi beban yang amat besar bagi orangtua, pengasuh, dan pemberi layanan kesehatan, termasuk tenaga keperawatan (Tork et al., 2007). Berdasarkan laporan World Health Organization (WHO), jumlah orang yang masih dalam ketergantungan terhadap orang lain mencapai 4-5\% dari seluruh populasi di dunia (WHO, 2002). Masalah ketergantungan melakukan perawatan diri sering terdapat pada kelompok anak (orang yang sangat muda), sangat tua, orang yang sakit atau orang yang cacat (Kittay, Jennings, \& Wasunna, 2005). Ketergantungan perawatan diri dijelaskan oleh WHO sebagai ketidakmampuan untuk melakukan kegiatan harian seperti mempertahankan kebersihan diri, makan, dan kesadaran akan bahaya sebagai salah satu masalah terbesar dalam kesehatan di dunia (WHO, 2002).

Survey Rumah Tangga oleh UNICEF dan University of Wisconsin (2008) memperoleh data yang memperlihatkan terdapat $52,4 \%$ anak usia 6-9 tahun yang berada di sekolah mengalami disabilitas atau ketidakmampuan melakukan aktivitas harian secara mandiri. Mont (2007) menyatakan disabilitas dapat menyebabkan seseorang terperangkap dalam kemiskinan karena adanya hambatan bagi seseorang dengan disabilitas untuk bersekolah, 
memperoleh pekerjaan, atau berpartisipasi dalam kegiatan sosial. Anak dengan disabilitas atau ketidakberdayaan membutuhkan pelayanan kesehatan dan ketersediaan dana yang tidak sedikit, sehingga dapat menjadi beban bagi keluarga, lingkungan, dan negara (Ehrenkrantz, et al., 2001).

Usia sekolah merupakan periode penting dalam tumbuh kembang anak. Pada tahap ini, anak menunjukkan karakteristik tersendiri dan belajar untuk melakukan aktivitas perawatan diri secara mandiri (Ling, 2008). Anak usia sekolah juga menghadapi konflik jika aktifitasnya terbatas, sehingga anak merasa bersalah, cemas, takut, atau bahkan menunjukkan perubahan perilaku yang tidak diharapkan (Pott \& Mandleco, 2007). Pada fase ini anak dapat berkembang menjadi kepribadian inferior (rendah diri). Salah satu penyebab timbulnya inferioritas pada anak adalah ketidakmampuan untuk melakukan perawatan diri secara mandiri.

The American Psychiatric Association's Diagnostic and Statistical Manual of Mental Disorder (DSM-IV-TR, 2000) mendefinisikan retardasi mental sebagai disfungsi atau gangguan yang terjadi pada susunan saraf pusat yang mengakibatkan kecerdasan intelektual (Intellectual Quetion) seseorang terukur di bawah 70, sehingga berdampak pada kemampuan untuk memenuhi kebutuhan dasarnya seperti keterampilan berkomunikasi, sosialisasi, pendidikan/belajar, kesehatan dan pekerjaan (Greydanus \& Pratt, 2005). Dunia pendidikan menyebut anak redardasi mental dengan sebutan tuna grahita. Seseorang yang memiliki kecerdasan mental dibawah normal (Greydanus \& Pratt, 2005; Effendi, 2006).

Ciri-ciri anak tuna grahita secara fisik dalam Sandra (2010), antara lain; 1) penampilan fisik tidak seimbang, misalnya kepala terlalu kecil/besar; 2) pada masa pertumbuhannya tidak mampu mengurus dirinya sendiri; 3) terlambat dalam perkembangan bicara dan bahasa; 4) tidak perhatian terhadap lingkungan; 5) koordinasi gerakan kurang; 6) hipersalivasi. Tingkah laku adaptif yang dimaksud pada anak tuna grahita adalah berupa kemampuan komunikasi, merawat diri, menyesuaikan dalam kehidupan rumah, keterampilan sosial, pemanfaatan sarana umum, mengarahkan diri sendiri, area kesehatan dan keamanan, fungsi akademik, pengisian waktu luang, dan kerja.

Data umum Badan Koordinasi Pendidikan Luar Biasa Karesidenan Banyumas (Bakor PLB) tahun 2008 mencatat jumlah anak berkebutuhan khusus yang berada di sekolah sebanyak 360 anak, sedangkan anak berkebutuhan khusus yang belum sekolah terdapat 1176 anak. Jumlah total anak berkebutuhan khusus di Kabupaten Banyumas adalah 1536 anak atau sekitar 0,1\% dari seluruh penduduk Kabupaten Banyumas. Jumlah anak tuna grahita tercatat berjumlah 490 anak (42\%) dari total jumlah 1176 anak berkebutuhan khusus. Sekolah Luar Biasa (SLB) Yakut Purwokerto memiliki siswa anak tuna grahita berjumlah 114 siswa yang terdiri dari 78 siswa SD, 31 siswa SMP, dan 15 siswa SMA. Namun hanya sekitar 90 siswa saja yang aktif bersekolah dari total siswa yang terdaftar (SLB Yakut Purwokerto, 2011). SLB Kuncup Mas, Kecamatan Banyumas memiliki 47 siswa tuna grahita dari seluruh siswa berkebutuhan khusus yang berjumlah 76 siswa (Bakor PLB, 2008).

Penelitian Ulfatulsholihat (2010) menyimpulkan bahwa anak tuna grahita memiliki keinginan didalam dirinya untuk dapat hidup mandiri dan tidak tergantung pada orangtua atau orang lain. Buyan (2004) menambahkan keterampilan perawatan diri (self-care) sebaiknya diajarkan di sekolah-sekolah, untuk mengembangkan keterampilan perawatan diri pada seseorang dibutuhkan informasi, media, dan bimbingan yang tepat. Anak dengan retardasi mental atau tuna grahita memiliki keterbatasan dalam kecerdasan intelektual yang berada dibawah rata-rata sehingga berdampak dalam penguasaan keterampilan melakukan perawatan diri secara mandiri, sehingga menyebabkan mereka mempunyai resiko yang tinggi untuk mengalami isolasi sosial di masyarakat karena kebersihan diri yang kurang dan ketergantungan yang besar pada keluarga. Pada akhirnya, hal ini dapat menyebabkan terbatasnya kesempatan yang sama dalam memperoleh pekerjaan kelak ketika mencapai usia dewasa. 
Keterbatasan kecerdasan intelektual tersebut bahkan sering diiringi dengan kelemahan fisik pada anak dengan tuna grahita.

Peningkatan kemampuan diri anak tuna grahita membutuhkan dukungan dan bimbingan dari berbagai pihak seperti keluarga, guru sekolah dan tenaga kesehatan sehingga mereka dapat mengembangkan kemampuan perawatan diri. Peran perawat anak dalam mendukung dan memberikan perhatian pada status kesehatan anak usia sekolah, khususnya yang mengalami retardasi mental atau tuna grahita sangat dibutuhkan baik oleh anak maupun keluarga (Maunder, 2006). Area ini menjadi tantangan bagi perawat anak, karena lamanya waktu interaksi yang dibutuhkan untuk memberikan bimbingan kepada anak dengan retardasi mental dan keluarga tidak dapat direncanakan secara pasti.

Berbagai faktor yang diuraikan diatas dapat berhubungan dengan kemampuan anak tuna grahita dalam melakukan perawatan diri secara mandiri. Untuk itu perlu diketahui faktor-faktor yang berpengaruh dan berperan dominan dalam melakukan kegiatan perawatan diri secara mandiri pada anak tuna grahita pada usia sekolah. Faktor-faktor tersebut dapat dimanfaatkan oleh perawat anak untuk mengembangkan intervensi keperawatan anak khususnya dalam melakukan optimalisasi tumbuh kembang dan kemandirian anak dalam memenuhi kebutuhan dasar, terutama anak-anak tuna grahita.

Penelitian ini ingin mengetahui tentang "Faktorfaktor yang berhubungan dengan kemampuan melakukan perawatan diri pada anak tuna grahita di Kabupaten Banyumas, Jawa Tengah”. Penelitian ini menggunakan Teori Perawatan Diri dari Dorothea Orema sebagai kerangka konsep. Keperawatan mandiri (self care) menurut Orem (2001) adalah kegiatan memenuhi kebutuhan dalam mempertahankan kehidupan, kesehatan dan kesejahteraan individu baik dalam keadaan sehat maupun sakit, dilakukan dan diprakarsai individu sendiri.

Pada anak dengan retardasi mental atau tuna grahita beberapa faktor yang mempengaruhi kemam- puan anak dalam memenuhi kebutuhan perawatan dirinya, antara lain adalah usia, fungsi kognitif, dan fungsi muskuloskeletal (Votroubek \& Tabacco, 2010). Faktor usia pada anak tuna grahita dihitung bukan hanya berdasarkan usia kronologis atau usia sejak anak dilahirkan, tetapi ditetapkan berdasarkan usia mental yang mengalami perkembangan selama 8 bulan setiap tahun kalender (Semiun, 2006).

Tabel 1. Distribusi Karakteristik Orangtua Anak Tuna Grahita

\begin{tabular}{|c|c|c|}
\hline Karakteristik De mografi & $\mathbf{N}$ & $(\%)$ \\
\hline \multicolumn{3}{|l|}{ Usia Ayah } \\
\hline a. $<45$ tahun & 34 & 52,3 \\
\hline b. $>45$ tahun & 31 & 47,7 \\
\hline \multicolumn{3}{|l|}{ Usia Ibu } \\
\hline a. $<42$ tahun & 31 & 47,7 \\
\hline b. $>42$ tahun & 34 & 52,3 \\
\hline \multicolumn{3}{|l|}{ Pendidikan } \\
\hline a. $\mathrm{SD}$ & 10 & 15,4 \\
\hline b. SMP & 12 & 18,5 \\
\hline c. SMA & 34 & 52,3 \\
\hline d. Akademi/PT & 9 & 13,8 \\
\hline \multicolumn{3}{|l|}{ Pekerjaan Ayah } \\
\hline a. Kerja lepas/tidak bekerja & 16 & 24,6 \\
\hline b. Petani & 4 & 6,2 \\
\hline c. Pedagang & 14 & 21,5 \\
\hline d. Karyawan swasta & 18 & 27,7 \\
\hline e. PNS & 13 & 20,0 \\
\hline \multicolumn{3}{|l|}{ Pekerjaan Ibu } \\
\hline a. Ibu rumah tangga & 49 & 75,4 \\
\hline b. Petani & 2 & 3,1 \\
\hline c. Pedagang & 9 & 13,8 \\
\hline d. PNS & 5 & 7,7 \\
\hline \multicolumn{3}{|l|}{ Pengeluaran Keluarga Per Bulan } \\
\hline a. $<500.000$ & 11 & 16,9 \\
\hline b. $500.000-1.500 .000$ & 34 & 52,3 \\
\hline c. $1.600 .000-2.500 .000$ & 10 & 15,4 \\
\hline d. $>2.500 .000$ & 10 & 15,4 \\
\hline \multicolumn{3}{|l|}{ Pola Asuh Orang tua } \\
\hline a. Demokratis & 39 & 60 \\
\hline b. Permisif & 26 & 40 \\
\hline \multicolumn{3}{|l|}{ Pengetahuan Orang tua } \\
\hline a. Pengetahuan rendah & 24 & 36,9 \\
\hline b. Pengetahuan tinggi & 41 & 63,1 \\
\hline
\end{tabular}


Jurnal Keperawatan Indonesia, Volume 15, No. 2, Juli 2012; hal 89-96

Fungsi kognitif memegang peranan penting dalam mempengaruhi kemampuan anak tuna grahita untuk mempelajari keterampilan perawatan diri atau aktivitas harian dan mencapai kemandirian. Sedangkan faktor fungsi musculoskeletal mempengaruhi kemampuan fisik anak tuna grahita untuk melakukan ambulasi dan merawat diri secara mandiri (Votroubek \& Tabacco, 2010).

Data di atas diperkuat oleh penelitian yang dilakukan oleh Tork, et al., (2007), mengidentifikasi faktor-faktor yang dapat mempengaruhi kemampuan perawatan diri pada anak usia sekolah adalah: faktor demografi (usia, jenis kelamin, status sosial ekonomi); faktor sosial kultural (budaya dan dukungan sosial); faktor psikososial (konsep diri, rasa percaya diri, dan tipe kepribadian); faktor fisik (kondisi kesehatan, kemampuan beraktivitas, disabilitas yang dialami). Anak yang berusia lebih tua memiliki kemampuan perawatan diri lebih baik dari anak dengan usia yang lebih muda (Wong, et al., 2002).

Kerangka kerja dari PEDI didasarkan pada ketidakmampuan (disablement), kontekstual dan perkembangan. PEDI terbukti dapat menjelaskan peningkatan atau kapabilitas anak dalam melakukan perawatan diri. Selain itu PEDI mampu menjelaskan perubahan fungsional pada anak, keluarga, pemberi asuhan utama, dan pihak lain yang terlibat dalam perawatan diri anak dan remaja. Ziviani, et al. (2001) melaporkan hasil uji validitas PEDI untuk mengukur kemampuan perawatan diri pada anak usia 6 bulan - 7,5 tahun dengan keterbatasan fisik dan kognitif adalah 0,80-0,97 dan reliabilitas menggunakan Cronbach $\alpha$ sebesar 0,95-0,99.

\section{Metode}

Penelitian ini merupakan penelitian kuantitatif dengan metode deskriptif observasional. Desain penelitian adalah cross sectional karena pengukuran faktor-faktor yang mempengaruhi kemampuan perawatan diri (variabel bebas) dan kemampuan perawatan diri pada anak tuna grahita (variabel terikat) dilakukan secara simultan pada saat bersama-
Tabel 2. Distribusi Karakteristik Anak Tuna Grahita

\begin{tabular}{|c|c|c|}
\hline Karakteristik Demografi & $\mathbf{N}$ & $(\%)$ \\
\hline \multicolumn{3}{|l|}{ Usia anak } \\
\hline a. Usia sekolah awal ( $<12$ tahun) & 30 & 46,2 \\
\hline b. Usia sekolah lanjut (= 12 tahun) & 35 & 53,8 \\
\hline \multicolumn{3}{|l|}{ Jenis kelamin } \\
\hline a. Laki-laki & 40 & 61,5 \\
\hline b.Perempuan & 25 & 38,5 \\
\hline \multicolumn{3}{|l|}{ Kelompok kelas } \\
\hline a. C (tuna grahita ringan) & 32 & 49,2 \\
\hline b. C1 (tuna grahita sedang) & 33 & 50,8 \\
\hline \multicolumn{3}{|l|}{ Struktur wajah } \\
\hline a. Mongoloid & 11 & 16,9 \\
\hline b. Normal & 54 & 83,1 \\
\hline \multicolumn{3}{|l|}{ Kekuatan motorik } \\
\hline a. Ada kelemahan motorik & 29 & 44,6 \\
\hline b. Tidak ada kelemahan motorik & 36 & 55,4 \\
\hline \multicolumn{3}{|l|}{ Hipersalivasi } \\
\hline a. Ada hipersalivasi & 18 & 27,7 \\
\hline b. Tidak ada hipersalivasi & 47 & 72,3 \\
\hline \multicolumn{3}{|l|}{$\begin{array}{l}\text { Tanda pre pubertas } \\
\text { (anak perempuan) }\end{array}$} \\
\hline a. Menstruasi & 18 & 72 \\
\hline b. Belum menstruasi & 7 & 28 \\
\hline \multicolumn{3}{|l|}{ Status gizi (IMT) anak } \\
\hline a. Underweight & 37 & 56,9 \\
\hline b.Normal & 17 & 26,2 \\
\hline c. Overweight & 11 & 16,9 \\
\hline
\end{tabular}

an untuk melihat adanya pengaruh atau tidak diantara keduanya (Pollit \& Beck, 2006), yaitu dalam penelitian ini dengan menggunakan kuesioner. Sampel penelitian ini adalah orangtua dari anak tuna grahita yang bersekolah di SLB YAKUT Kecamatan Purwokerto Selatan dan SLB KUNCUP MAS Kecamatan Banyumas, usia anak tuna grahita 9-17 tahun, kategori tuna grahita ringan atau sedang, dan bertempat tinggal di wilayah Kabupaten Banyumas, yaitu berjumlah 65 orangtua siswa dengan 45 orangtua siswa SLB YAKUT dan 20 orangtua siswa SLB KUNCUP MAS. 
Instrumen yang digunakan dalam penelitian ini berupa kuesioner kemampuan diri memodifikasi instrumen PEDI dan teori self-care dari Orem. Kemampuan yang diukur adalah kemampuan melakukan perawatan diri pada anak tuna grahita meliputi aspek kebutuhan perawatan diri universal, kebutuhan perawatan diri sesuai perkembangan anak, dan kebutuhan perawatan diri pada kondisi adanya penyimpangan kesehatan. Hasil ukur menggunakan total nilai pengukuran dengan skor 63-189.

\section{Hasil}

Pada tabel 1 didapatkan 34 orang ayah $(52,3 \%)$ berusia $<45$ tahun, 34 orang $(52,3 \%)$ ibu berusia $<2$ tahun, pendidikan ibu 52,3\% SMA, pekerjaan ibu 75,4\% ibu rumah tangga; pengeluaran keluarga paling banyak berada dalam rentang Rp500.000Rp1.500.000; sebanyak 60\% keluarga menerapkan pola asuh demokratis dan $60 \%$ orangtua masuk kategori pengetahun tinggi tentang anak tuna grahita.

Hasil analisis karakteristik fisik 65 anak tuna grahita didapatkan anak tuna grahita dengan sebanyak 40 anak $(61,5 \%)$ berjenis kelamin laki-laki. Terdapat 33 anak $(50,8 \%)$ yang berada di kelas $\mathrm{C} 1$ atau kategori tuna grahita sedang dan sebanyak 32 anak berada pada kelas $\mathrm{C}$ atau kategori tuna grahita ringan (49,2\%). Sebanyak 11 anak (16,9\%) dengan struktur wajah Mongoloid dan sisanya $(83,1 \%)$ memiliki struktur wajah non Mongoloid (normal). Anak tuna grahita yang mengalami hipersalivasi sebanyak 18 anak $(27,7 \%)$.

Pada perkembangan anak didapatkan 25 anak tuna grahita dengan jenis kelamin perempuan dan 18 anak $(72 \%)$.yang telah menstruasi. Anak tuna grahita usia $<12$ tahun sebanyak 30 anak (46,2\%). Anak tuna grahita yang mengalami underweight ada 37 anak (56,9\%), normal 17 anak (26,2\%) dan overweight 11 anak (16,9\%).

Hasil analisis menunjukkan 40 responden $(61,5 \%)$ dari total 65 responden yang menyatakan dukungan rendah terhadap anak tuna. Dari 65 responden anak tuna grahita, yang menggunakan alat bantu
Tabel 3. Distribusi Responden Berdasarkan Karakteristik Lingkungan

\begin{tabular}{lcc}
\hline $\begin{array}{c}\text { Dukungan Lingkungan dan } \\
\text { Alat Bantu }\end{array}$ & $\mathbf{N}$ & $\mathbf{( \% )}$ \\
\hline $\begin{array}{c}\text { Dukungan guru dan tenaga kes ehatan } \\
\text { Dukungan rendah }\end{array}$ & 40 & 61,5 \\
Dukungan tinggi & 25 & 38,5 \\
Alat bantu penglihatan & 6 & 9,2 \\
Alat bantu pendengaran & 3 & 4,6 \\
Alat bantu pergerakkan & 5 & 7,7 \\
\hline
\end{tabular}

penglihatan kacamata hanya 6 anak $(9,2 \%)$, alat bantu pendengaran 3 anak $(4,6 \%)$ dan alat bantu pergerakan (misal: kruk, kursi roda, dan lain-lain) hanya 5 anak $(7,7 \%)$. Tidak ada anak tuna grahita yang terlibat dalam penelitian ini menggunakan alat bantu pernafasan.

Kemampuan perawatan diri anak tuna grahita dinilai melalui kemampuan untuk melakukan sembilan area perawatan diri yaitu (1) kebersihan diri, (2) makan dan (3) minum, (4) berpakaian, (5) mobilisasi, (6) pergerakkan, (7) sosialisasi, (8) membantu pekerjaan rumah tangga, dan (9) perlindungan diri.

Tabel 4 dan 5 menunjukkan jumlah area kemampuan perawatan diri yang belum mampu dilakukan oleh anak tuna grahita tanpa bantuan dari orang lain. Hasil analisis menunjukkan anak tuna grahita yang telah mampu melakukan aktivitas perawatan diri tanpa bantuan di 7 area 3,1\%, 6 area 10,8\%, 5 area $7,7 \%$. Sedangkan anak tuna grahita yang hanya mampu melakukan aktivitas perawatan diri $<3$ area $61,6 \%$.

Tingkat kemampuan perawatan diri anak tuna grahita selanjutnya dikelompokkan berdasarkan jumlah area kegiatan perawatan diri yang dilakukan oleh anak tuna grahita dengan dan tanpa bantuan dari orang lain, yaitu kemampuan perawatan diri rendah jika anak tidak mampu mandiri pada 7-9 area $(61,6 \%)$ dan kemampuan perawatan diri tinggi jika tidak mampu mandiri pada $<7$ area $(38,4 \%)$. 
Hasil analisis uji statistik Chi-Square menunjukkan tidak terdapat hubungan bermakna antara karakteristik orangtua (usia ayah, usia ibu, pendidikan terakhir orangtua, pekerjaan ayah, pekerjaan ibu, pengeluaran keluarga, pengetahuan orangtua dan pola asuh orangtua) terhadap kemampuan perawatan diri anak tuna grahita $(\mathrm{p}>0,05)$. Dan tidak terdapat hubungan yang bermakna antara karakteristik lingkungan dengan kemampuan perawatan diri anak tuna grahita.

Pada analisis hubungan antara karakteristik anak dengan kemampuan perawatan diri didapatkan hasil yang menunjukkan tidak terdapat hubungan bermakna antara karakteristik anak (jenis kelamin, kelompok kelas, hipersalivasi, status gizi, dan perkembangan anak dengan kemampuan perawatan diri anak tuna grahita $(\mathrm{p}>0,05)$. Ada hubungan bermakna antara karakteristik anak (usia anak, struktur wajah, dan kekuatan motorik) dengan kemampuan perawatan diri anak $(\mathrm{p}<0,05)$.

Pada analisis multivariat, kandidat dalam model adalah variabel yang mempunyai hubungan dengan variabel terikat dengan nilai $\mathrm{p} \leq 0,25$. Maka variabel bebas yang masuk sebagai kandidat dalam model adalah variabel karakteristik orangtua, yaitu pendidikan orangtua, karakteristik lingkungan yaitu dukungan guru dan tenaga kesehatan serta variabel karakteristik anak, yaitu usia anak, jenis kelamin

Tabel 4. Distribusi Responden Berdasarkan Jumlah Area Ketidakmampuan Perawatan Diri Anak Tuna Grahita

\begin{tabular}{ccc}
\hline $\begin{array}{c}\text { Jumlah Area Ketidakmampuan } \\
\text { Perawatan Diri }\end{array}$ & N & (\%) \\
\hline 2 & 2 & 3,1 \\
3 & 7 & 10,8 \\
4 & 5 & 7,7 \\
5 & 7 & 10,8 \\
6 & 4 & 6,2 \\
7 & 15 & 23,1 \\
8 & 12 & 18,5 \\
9 & 13 & 20,0 \\
\hline
\end{tabular}

anak, kelompok kelas, struktur wajah, kekuatan motorik, hipersalivasi dan status gizi anak (IMT).

Pada tabel 6 terlihat orangtua dengan pendidikan terakhir SMA memiliki peluang 3,12 kali untuk meningkatkan kemampuan perawatan diri pada anak tuna grahita dibandingkan orangtua dengan pendidikan terakhir yang lebih rendah. Faktor yang berhubungan paling dominan dengan kemampuan perawatan diri anak tuna grahita adalah faktor kekuatan motorik $(p=0,012 ; \alpha=0,05)$.

Anak tuna grahita tanpa kelemahan motorik mempunyai kemampuan perawatan diri lebih baik sebesar 5 kali bila dibandingkan anak tuna grahita dengan kelemahan motorik $(\mathrm{OR}=4,77)$. Uji interaksi dilakukan untuk menilai apakah ada interaksi antara variabel pendidikan orangtua, usia anak, dan kekuatan motorik pada anak tuna grahita. Hasil uji interaksi didapatkan $\mathrm{p}=0,10$ (lampiran), berarti lebih besar dari 0,05. Sehingga dapat disimpulkan tidak ada interaksi antar variabel yang masuk ke dalam pemodelan.

\section{Pembahasan}

Kemampuan perawatan diri pada anak tuna grahita usia 9 - 17 tahun pada penelitian ini mayoritas berada pada kategori kemampuan perawatan diri yang rendah. Pada penelitian ini didapatkan anak tuna grahita yang telah mampu melakukan perawatan diri tanpa bantuan di lebih dari 2 area sebanyak $38,6 \%$ dan sisanya masih membutuhkan bantuan.

Karakteristik anak tuna grahita menurut Sandra (2010) salah satunya adalah mengalami kesulitan dalam melakukan perawatan diri dan hidup bermasyarakat. Anak dengan disabilitas yang parah dapat menjadi sangat tergantung pada orangtua atau pengasuh (Harvey, 2004). Sebaliknya, pada penelitian Buckley, et al., (2006) melaporkan bahwa anak Down Syndrome (DS) yang bersekolah di sekolah pendidikan khusus memperlihatkan kemampuan sosialisasi dan perawatan diri yang sangat baik, namun mengalami keterlambatan dalam kemampuan komunikasi. 
Tabel 5. Tingkat Kemampuan Perawatan Diri Anak Tuna Grahita

\begin{tabular}{lll}
\hline Kemampuan Perawatan Diri & N & (\%) \\
\hline Rendah & 40 & 61,6 \\
Tinggi & 25 & 38,4 \\
\hline
\end{tabular}

Penelitian ini mengamati kemampuan perawatan diri pada anak tuna grahita usia 9-17 tahun yang bersekolah di Sekolah Luar Biasa (SLB) dan mendapatkan bahwa anak tuna grahita dalam penelitian ini terkategorikan mempunyai kemampuan perawatan diri rendah berdasarkan area kegiatan perawatan diri yang dapat dilakukan oleh anak tanpa bantuan, menurut kuesioner skala modifikasi dari PEDI. Menurut Orem (2001), bahwa pada kebutuhan perawatan diri sebagian (partially compensatory system), membutuhkan bantuan perawat dalam pengkajian penentuan kebutuhan perawatan diri klien, menyediakan kebutuhan perawatan diri akibat keterbatasan dan membantu klien sesuai yang dibutuhkan.

Kemampuan perawatan diri anak tuna grahita terkategorikan rendah, masih membutuhkan bantuan di sebagian besar area dan memperlihatkan masih adanya keterbatasan pemenuhan kebutuhan perawatan diri pada anak tuna grahita. Dalam penelitian ini, masih terlihat kemampuan perawatan diri yang rendah pada anak tuna grahita di lebih dari 2 area. Sehingga dapat disimpulkan bahwa anak tuna grahita masih membutuhkan adanya bimbingan dan pelatihan yang berkesinambungan baik dari orangtua, guru atau tenaga kesehatan khususnya perawat sebagai agen perawatan diri yang dapat membantu anak tuna grahita meningkatkan dan mengembangkan kemampuan perawatan dirinya.

Implikasi penelitian ini yaitu masih diperlukannya latihan terstruktur untuk anak tuna grahita dan keluarganya. Perawat anak bersama sekolah diharapkan mengembangkan program keterampilan kemampuan perawatan diri secara bertahap yang hasilnya dievaluasi bersama perawat, guru dan keluarga, sehingga kemampuan anak merawat dirinya secara mandiri dapat dicapai secara optimal. Tujuan jangka panjang diharapkan anak mampu menjadi insan yang memiliki citra diri yang positif dan mampu bersosialisasi di masyarakat. Penelitian lanjutan adalah membuat model pendidikan terintegrasi anak tuna grahita di sekolah, rumah, dan masyarakat.

\section{Kesimpulan}

Hasil penelitian menunjukkan bahwa terdapat hubungan yang signifikan antara karakteristik anak yaitu usia dan kondisi fisik anak (kekuatan motorik dan hipersalivasi) dengan kemampuan perawatan diri anak tuna grahita. Usia anak yang lebih tua ( $\geq 12$ tahun) mempunyai kemampuan perawatan diri 4,6 kali lebih baik dibandingkan anak dengan usia yang lebih muda ( $<12$ tahun). Orangtua dengan pendidikan terakhir SMA memiliki peluang 3,12 kali untuk meningkatkan kemampuan perawatan diri pada anak tuna grahita dibandingkan orangtua dengan pendidikan terakhir yang lebih rendah. Kondisi fisik (kekuatan motorik) anak merupakan faktor paling dominan yang berhubungan dengan kemampuan perawatan diri anak tuna grahita,

Tabel 6. Faktor-Faktor yang Berhubungan dengan Kemampuan Perawatan Diri Anak Tuna Grahita

\begin{tabular}{lccccc}
\hline \multicolumn{1}{c}{ Variabel } & B & Wald & p & OR & $\mathbf{9 5 \% ~ C I ~}$ \\
\hline Pendidikan orang tua & 1,138 & 2,916 & 0,088 & 3,121 & $0,845-11,522$ \\
Usia anak & 1,546 & 6,274 & 0,12 & 4,695 & $1,400-15,746$ \\
Kekuatan motorik & 1,563 & 1,563 & 0,012 & 4,772 & $1,401-16,249$ \\
Constant & $-3,110$ & 13,077 & 0,000 & 0,45 & \\
\hline
\end{tabular}


yaitu anak tuna grahita yang tidak memiliki kelemahan motorik 4,77 kali lebih mampu melakukan perawatan diri dibandingkan anak tuna grahita dengan kelemahan motorik (WK, YR, RR).

\section{Referensi}

Bakor PLB. (2008). Laporan pendataan PK dan PLK di Karesidenan Banyumas tahun 2008. Banyumas: Badan Koordinasi PLB Banyumas.

Buckley, S., Bird, G., \& Sacks, B. (2006). Evidence based that we can change the profile from a study of inclusive education. Down Syndrome: Res Pract, 9, 51-53.

Buyan, K.K. (2004). Health promotion through selfcare and community participation: Elements of a proposed programme in the developing countries. BMC Public Health, 4, 11. Doi:10.1186/14712458-4-11.

Effendi, M. (2006). Pengantar psikopedagodik anak berkelainan. Jakarta: PT. Bumi Aksara.

Ehrenkrantz, D., Miller, C., Vernberg, D.K., \& Fox, M.H. (2001). Measuring prevalence of childhood disability: Addressing family needs while augmenting prevention. Journal of Rehabilitation. 2 (67), 48-54.

Greydanus, D.E., \& Pratt, H.D. (2005). Syndromes and disorders associated with mental retardation. Indian Journal of Pediatrics, 72, 859-864.

Kittay, E., Jennings, B., \& Wasunna, A. (2005). Dependency, difference and the global ethic of longterm care. J. Polit. Philos, 13, 443-469.

Ling, F. (2008). Self-care behaviors of school-aged children with heart disease. Pediatric Nursing Journals, 34 (2), 131-138.

Pott, N.K., \& Mandleco, B.L. (2007). Pediatric nursing: Caring for children and their families (2nd Ed.). New York: Thompson Corp.
Mont, D. (2007). Measuring disability prevalence. Discussion Paper. Social Protection: The World Bank.

Orem, D.E. (2001). Nursing: concept of practice (6th Ed.). St. Louis: Mosby Inc.

Sandra, M. (2010). Anak cacat bukan kiamat: Metode pembelajaran dan terapi untuk anak berkebutuhan khusus. Yogyakarta: Katahati.

Ulfatulsholihat, R. (2010). Peran orangtua dalam penyesuaian diri anak tuna grahita. Jurnal Universitas Gunadarma, Jakarta.

UNICEF \& University of Winconsin. (2008). Monitoring child disability in developing countries: Result from the multiple indicator cluster surveys (MICS). Diperoleh dari www49.ws 10.tijdelijke-url.nl/data/1239015 075183 UNICEF\%2520survey\%2520response. doc

Votroubek, W., \& Tabbaco, A. (2010). Pediatric home care for nurses: A family-centered approach (3rd Ed.). Sudbury, MA: Jones \& Bartlett's Publishers.

Wong, D.L. et al. (2009). Buku ajar keperawatan pediatrik (Volume 1, Edisi 6). (Agus Sutarna, Neti Juniarti, \& H.Y. Kuncara, penerjemah). Jakarta: EGC Penerbit Buku Kedokteran.

World Health Organization. (2002). Current and future longterm care needs: An analysis based on the 1990 WHO study. Diperoleh dari http:// www.who.int/entity/chp/knowledge/publication/ ltc_needs.pdf.

Ziviani, J., Ottenbacher, K. J., Shephard, K., Foreman, S., Astbury, W., \& Ireland, P. (2001). Concurrent validity of the functional independence measure for children (WeeFMTM) and pediatric evaluation of disability inventory (PEDI) in children with developmental disabilities and acquired brain injuries. Physical and Occupational Therapy in Pediatrics, 21, 2-3. 